\title{
Pengangguran Di Tengah Puncak Bonus Demografi Pada Era Pandemi Covid-19
}

\author{
Rizka Azzahra
}

\begin{abstract}
Demographers predict that in the period 2020-2030 Indonesia will experience a demographic bonus with a peak around 2030. At that time, the number of people with productive age in Indonesia, namely the age range of 15-64 years, far exceeds those who are included in the nonproductive age (children and the elderly). The Demographic Bonus should be a very positive thing where Indonesia can get extraordinary benefits, making Indonesia have high competitiveness and bargaining power. But on the other hand, Indonesia is currently facing serious problems due to the impact of the Covid-19 pandemic that has hit the world. Social distancing (physical distancing) carried out to anticipate the spread and expansion of the Covid 19 pandemic has made changes in various fields, both in the economy, transportation, worship, education, government and entertainment that have a direct impact on labor. The number of job cuts that occurred during the Covid-19 pandemic had a huge impact because not all of the workforce could be accommodated in the world of work, as a result it would encourage an increase in the number of unemployed in Indonesia. This study aims to analyze the dynamics of unemployment in Indonesia and the steps that need to be taken by the government and the Indonesian people in order to face the era of demographic bonuses in the midst of the Covid-19 pandemic so that this demographic bonus does not become a wave of mass unemployment in Indonesia.
\end{abstract}

Keywords: Demography, Unemployment, Impact of the Covid 19 Pandemic, Termination of Employment

\begin{abstract}
Abstrak
Para ahli demografi memprediksikan dalam rentang waktu 2020-2030 Indonesia mengalami bonus demografi dengan masa puncak di sekitar tahun 2030. Pada saat-saat itu jumlah masyarakat dengan usia produktif di Indonesia yaitu dengan kisaran umur 15-64 tahun jauh lebih banyak melebihi mereka yang termasuk dalam usia non-produktif (anak-anak dan lansia). Bonus Demografi seharusnya merupakan hal yang sangat positif dimana Indonesia bisa mendapatkan keuntungan yang luar biasa, membuat Indonesia memiliki daya saing dan daya tawar yang tinggi. Namun di sisi lain Indonesia saat ini menghadapi permasalahan serius akibat dampak dari pandemi Covid-19 yang melanda dunia. Social distancing (physical distancing) yang dilakukan guna mengantisipasi persebaran dan perluasan pandemi Covid 19 telah membuat perubahan di berbagai bidang, baik dalam ekonomi, transportasi, peribadatan, pendidikan, pemerintahan, dan hiburan yang berdampak langsung terhadap tenaga kerja. Banyaknya pemutusan hubungan kerja yang terjadi selama masa pandemi Covid-19 ini tentunya sangat berdampak besar karena tidak semua angkatan kerja dapat tertampung didunia kerja, akibatnya akan mendorong terjadinya peningkatan jumlah pengangguran di Indonesia. Kajian ini bertujuan untuk menganalisis dinamika pengangguran di Indonesia dan langkahlangkah yang perlu dilakukan oleh pemerintah dan masyarakat Indonesia dalam rangka menghadapi era bonus bonus demografi ditengah pandemi Covid-19 ini agar bonus demografi ini tidak menjadi sebuah gelombang pengangguran massal di Indonesia.
\end{abstract}

Kata Kunci : Demografi, Pengangguran, Dampak Pandemi Covid 19, Pemutusan Hubungan Kerja 


\section{Pendahuluan}

Populasi penduduk dunia diperkirakan oleh Perserikatan Bangsa-Bangsa (PBB) pada tahun 2015 dalam The 2015 Revision of World Population Prospects mencapai 8,5 miliar pada tahun 2030, akan meningkat menjadi 9,7 miliar pada tahun 2050, dan diproyeksi akan melampaui 11 miliar pada tahun 2100. Jumlah penduduk India diperkirakan akan melampaui Tiongkok, sebagai negara berpenduduk paling padat di dunia 7 tahun mendatang, dan Nigeria di perkirakan akan melampaui Amerika Serikat untuk menjadi negara terbesar ketiga di dunia dalam 35 tahun mendatang. Sepuluh negara dengan kesuburan terbesar di dunia saat ini, salah satunya Nigeria yang berada di Afrika, lima negara berada di Asia yaitu (Bangladesh, Tiongkok, India, Indonesia, dan Pakistan), dua negara berada di Amerika Latin (Brasil dan Meksiko), satu negara di Amerika Utara (AS), dan satu negara di Eropa (Federasi Rusia). Masuknya Indonesia dalam kategori negara dengan tingkat pertumbuhan penduduk terbesar di dunia sangat berkaitan dengan istilah bonus demografi yang dialami oleh Indonesia.

Menurut para ahli demografi Indonesia tengah mengalami fenomena transisi demografi, tahun 2020-2030 Indonesia akan mendapat bonus demografi dengan masa puncak di sekitar tahun 2030. Kondisi bonus demografi ini terindikasi dari hasil sensus penduduk yang dilakukan pada tahun 2000 yang memberikan hasil bahwa bahwa program KB (Keluarga Berencana) pada kurun waktu yang lalu memberi dampak yang sangat positif dengan penurunan yang cukup tajam mencapai 1,44 persen pada tahun 2015. Dari data yang diperoleh Sensus Penduduk pada tahun 2015 memperlihatkan bahwa jumlah penduduk Indonesia yang berusia dibawah 15 tahun terdapat sangat sedikit peningkatan, dimana pada periode tahun 1970-1980 jumlahnya tercatat lebih dari 60 juta dan hingga akhir tahun 2000 penduduk dalam kelompok usia ini hanya meningkat menjadi lebih dari 69 juta jiwa. Sebaliknya, penduduk usia 15 - 64 tahun pada tahun 1970 jumlahnya mencapai lebih dari 64 juta jiwa dan telah berkembang menjadi lebih dari 138 juta jiwa, atau mengalami kenaikan lebih dari dua kali lipat.

Beban ketergantungan penduduk Indonesia jika diukur dari ratio penduduk usia anak-anak dan usia tua perpenduduk usia kerja, maka dapat dilihat bahwa tingkat ketergantungan penduduk Indonesia menunjukkan penurunan yang cukup tajam, dimana pada tahun 1970 nilainya sekitar 85-90 per 100 dan menurun hingga ke level sekitar 49 per 100 di tahun 2015 . Hasil sensus penduduk tahun 2015 juga menunjukkan trend positif pada penduduk usia produktif (15-64 tahun), dimana pada tahun 2015 porsinya mencapai 66 persen dari total penduduk yang jumlahnya mencapai 157 juta jiwa. Sedangkan jumlah penduduk usia muda (15-24tahun) mencapai 26,8. Kenaikan angka usia produktif kerjatersebut menyebabkan semakin kecilnya nilai angka ketergantungan menjadi 49, berarti 100 penduduk usia produktif menanggung 49 orang penduduk tidak produktif (di bawah 15 tahun dan di atas 64 tahun). Menurut United Nations transisi demografi yang terjadi pada beberapa dekade terakhir di Indonesia akan membuka peluang bagi Indonesia untuk menikmati bonus demografi (demographic devident) pada periode tahun 2020-2030.

Bonus Demografi seharusnya merupakan hal yang sangat positif bagi Indonesia dimana Indonesia bisa mendapatkan keuntungan yang luar biasa dari tingginya proporsi usia angkatan kerja yang membuat Indonesia berkesempatan memiliki daya saing dan daya tawar yang tinggi. Dengan tingginya usia angkatan kerja produktif iklim investasi dan bisnis menjadi lebih segar karena diisi dengan berbagai pemikiran pemikiran muda nan kreatif. Kondisi ini juga dikenal sebagai jendela kesempatan (windows of oppprtunity) bagi sebuah negara untuk melakukan kebijakan dengan menggenjot industri manufaktur, infrastruktur, maupun UKM karena berlimpahnya angkatan kerja. Kondisi ini juga seharusnya akan membuat investor semakin tertarik membelanjakan uangnya Indonesia, yang secara otomatis akan makin membuka peluang pekerjaan lebih melimpah. Transisi struktur penduduk ini diharapkan menjadi momentum yang tepat untuk mendorong Indonesia menjadi besar dan maju, jika ditopang jumlah penduduk produktif. Tingginya jumlah dan proporsi penduduk usia produktif Indonesia, selain meningkatkan angkatan kerja di dalam negeri, juga membuka peluang untuk mengisi kebutuhan 
tenaga kerja di negara sekitar yang proporsi penduduk usia kerjanya menurun, seperti Singapura, Korea, Jepang, dan Australia.

Global Competitiveness Index pada tahun 2018 menunjukkan, daya saing tenaga kerja Indonesia termasuk yang paling kecil di Asia Tengara. Indonesia berada pada peringkat ke-45, jauh di bawah negara tetangga Singapura yang menduduki peringkat 2, Malaysia menduduki peringkat 25 , dan Thailand menduduki peringkat 38. Tingkat produktivitas tenaga kerja Indonesia juga bisa dikatakan masih rendah. Jika dilihat dari data yang ada proyeksi tenaga kerja Indonesia yang mungkin diserap oleh negara asing pun mungkin akan sangat minim. Peluang kerja diluar Indonesia pun terlihat semakin terbatas dikarenakan pandemi Covid-19 banyak negara di dunia yang menutup bordernya untuk warga negara asing, sehingga semakin minimnya peluang kerja bagi penduduk usia produktif.

Social distancing (physical distancing) yang dilakukan guna mengantisipasi persebaran dan perluasan pandemi Covid-19 telah membuat perubahan di berbagai bidang, baik dalam ekonomi, transportasi, peribadatan, pendidikan, pemerintahan, dan hiburan yang berdampak langsung terhadap tenaga kerja. Banyaknya pemutusan hubungan kerja yang terjadi selama masa pandemi Covid-19 ini tentunya sangat berdampak besar karena tidak semua angkatan kerja dapat tertampung didunia kerja, akibatnya akan mendorong terjadinya peningkatan jumlah pengangguran di Indonesia. Menurut data Badan Pusat Statistik 2020 jumlah pengangguran di Indonesia bertambah 2,67 juta orang akibat pandemi Covid-19, yaitu dari 7,1 juta orang menjadi 9,77 juta orang atau dari 5,23 persen ke 7,07 persen. Hal ini sejalan dengan maraknya Pemutusan Hubungan Kerja (PHK) akibat sudah tak tahan melawan pandemi. Kajian ini bertujuan untuk menganalisis dinamika pengangguran di Indonesia dan langkah-langkah yang perlu dilakukan oleh pemerintah dan masyarakat Indonesia dalam rangka menghadapi era bonus bonus demografi ditengah pandemi Covid-19 ini agar bonus demografi ini tidak menjadi sebuah gelombang pengangguran massal di Indonesia.

\section{Metode Penelitian}

Metode yang digunakan dalam penelitian ini adalah kajian literatur menggunakan metode analisa deskriptif- kualitatif berbasis kajian kepustakaan (library research). Data-data yang berkaitan dengan pertumbuhan penduduk, tingkat pengangguran dan tenaga kerja di Indonesia di analisa secara deskriptif menggunakan pemetaan permasalahan yang terdapat dalam variable atau kasus yang sedang dikaji dan kemudian dihubungkan dengan keadaan pandemi Covid-19. Kajian di korelasi agar bisa mengkonfirmasi, menolak, dan seimbang berdasarkan pada data dan informasi yang berhasil dilakukan oleh peneliti.

\section{Hasil Dan Pembahasan}

\section{A. Bonus Demografi}

Bonus demografi adalah sebuah istilah dalam ilmu kependudukan (demografi), bonus demografi merupakan kondisi dimana jumlah penduduk usia produktif melebihi jumlah penduduk yang tidak dalam usia produktif. Kondisi Bonus demografi ini didapat atas keberhasilan program Keluarga Berencana yang dicanangkan sejak tahun 1960. Istilah bonus demografi sering dikaitkan dengan angka ketergantungan penduduk (Dependency Ratio). Angka ketergantungan adalah sebuah perbandingan antara jumlah penduduk pada usia produktif dengan non produktif yang dikalikan 100. Usia non produktif adalah anak yang berusiha di bawah usia 15 tahun dan lansia yang berusia di atas 64 tahun. Angka ketergantungan tersebut menggambarkan berapa banyak penduduk usia non produktif yang hidupnya harus ditanggung oleh kelompok penduduk usia produktif. Angka ketergantungan Indonesia pada tahun 2015 adalah sekitar 49. Artinya bahwa setiap 100 penduduk usia produktif di Indonesia menanggung sekitar 49 penduduk usia non produktif. 
Gambar 1.1 Rasio Ketergantungan Penduduk Indonesia Tahun 1971 - 2015

\section{RASIO KETERGANTUNGAN}

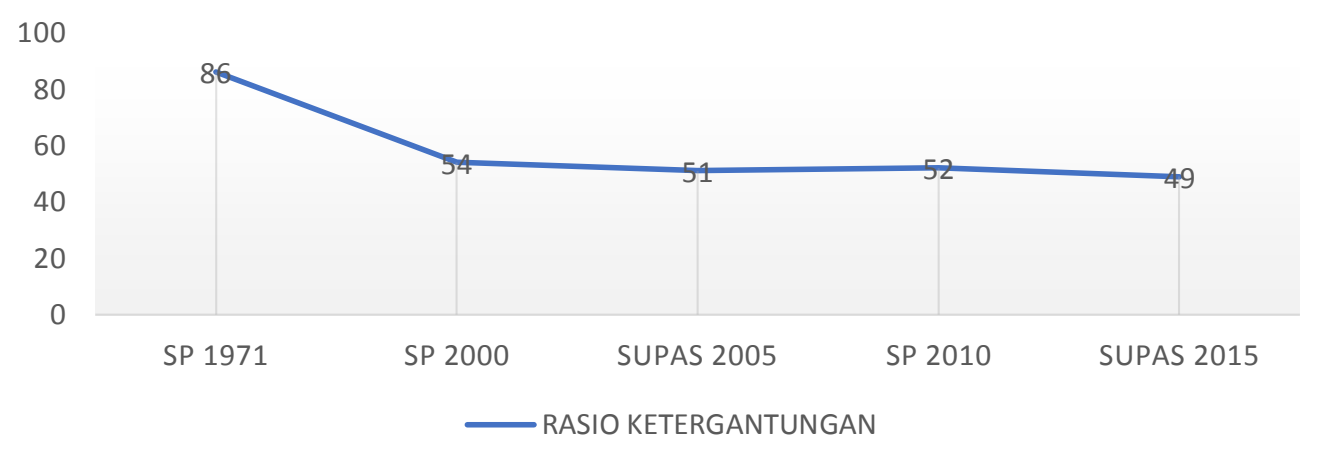

Sumber Data Sensus Penduduk Tahun 1971, 2000, 2010 dan Supas 2005, 2015

Angka ketergantungan Indonesia tercatat terus menerus menurun. Berdasarkan data Badan Pusat Statistik, pada tahun 1971 sebesar 86, pada tahun 2000 menjadi 54 dan pada tahu 2010 sebesar 52. Penurunan angka ketergantungan penduduk terus terjadi dikarenakan semakin meningkatnya jumlah penduduk usia produktif yang diperkirakan akan terus berlangsung sampai pada tahun 2030. Menurut Dr Sukamdi, peneliti dari Pusat Studi Kependudukan dan Kebijakan (PSKK) Universitas Gadjah Mada (UGM), bonus demografi yang diterima Indonesia tahun 2020 sangat menguntungkan. Pada kondisi bonus demografi masyarakat di proyeksi akan memperoleh pendapatan lebih tinggi dengan dana tabungan yang lebih banyak. Pada fase bonus demografi tingkat ketergantungan (dependency ratio) penduduk usia tidak produktif kepada penduduk usia produktif cenderung lebih rendah.

Berdasarkan data dan proyeksi yang dilakukan oleh Badan Pusat Statistik, jumlah penduduk usia produktif Indonesia pada tahun 2020 diperkirakan mencapai sekitar 203,97 juta jiwa dan akan meningkat lagi pada tahun 2025 hingga 2030. Hal tersebut mempunyai konsekuensi pada pentingnya peningkatan kualitas sumber daya manusia penduduk Indonesia serta penyediaan lapangan kerja produktif bagi penduduk usia kerja ini. Jika hal ini bisa dilakukan maka besarnya perkembangan penduduk usia kerja akan menjadi pendorong pertumbuhan ekonomi Indonesia yang sangat potensial dan mampu bersaing di pasar global. Sebaliknya jika tidak ada kebijakan pemerintah yang berpihak pada penyerapan tenaga kerja, maka akan sangat mungkin jumlah pengangguran di Indonesia akan sangat tinggi.

Ledakan penduduk usia kerja ini akan memberikan keuntungan ekonomi apabila memenuhi persyaratan sebagai berikut (Jati, 2013):

1. Penawaran tenaga kerja (laborsupply) yang besar dengan kualitas yang memenuhi kebutuhan pasar tenaga kerja

2. Meningkatkan pendapatan perkapita karena mendapat kesempatan kerja yang produktif

3. Peningkatan peranan kaum perempuan di pasar tenaga kerja karena jumlah anak yang semakin sedikit memungkinkan perempuan memasuki pasar kerja dan membantu peningkatan pendapatan keluarga

4. Terjadi peningkatan tabungan (savings) masyarakat yang diinvestasikan secara produktif

5. Adanya peningkatan investasi sumber daya modal manusia (human capital)

Ada beberapa hal yang menjadi penyebab pertumbuhan ekonomi tidak berkualitas sehingga kurang peduli terhadap bonus demografi diantaranya dapat dilihat dari:

1. Terjadinya ketimpangan Indeks Pembangunan Manusia (IPM) antar provinsi, dimana IPM yang tinggi masih didominasi oleh bagian Barat dan Tengah seperti DKI Jakarta, DIY, Riau,Sulawesi Utara, Sumatera Utara,Sumatera Barat, dan Sumatera Selatan. 
Sedangkan IPM rendah dimiliki oleh Papua, Maluku, Maluku Utara, NTB,dan NTT.

2. Terjadinya ketimpangan indeks angka melek huruf, dimana Penduduk kota Jakarta mempunyai melek huruf 99 persen dengan rata-rata lama sekolah 10,9 tahun dan merupakan kota dengan nilai IPM tertinggi di Indonesia. Tetapi Mataram memiliki nilai melek huruf 95 persen dan rata-rata lama sekolah 7,4 tahun berada pada urutan IPM nomor 198 dan penduduk Jayawijaya hanya mempunyai melek huruf 32 persen dan rata-rata pendidikan 2,2 tahun berada jauh pada urutan IPM ke 341 dari seluruh kabupaten dan kota yang ada diIndonesia.

3. Terjadinya Ketimpangan ngka ketercukupan gizi dimana di kawasan Indonesia Timur masih mendominasi angka gizi buruk pada penduduknya,angka gizi buruk yang tertinggi justru terjadi di wilayah dengan kekayaan sumber alam melimpah, seperti Papua dan Papua Barat.

Global Competitiveness Index pada tahun 2018 menunjukkan, daya saing tenaga kerja Indonesia termasuk yang paling kecil di Asia Tengara. Tingkat produktivitas tenaga kerja Indonesia juga bisa dikatakan masih rendah. Dengan melihat masih besarnya angka ketimpangan pembangunan manusia di Indonesia dan jika dilihat dari data yang ada proyeksi tenaga kerja Indonesia yang mungkin diserap oleh negara asing pun mungkin akan sangat minim. Peluang kerja diluar Indonesia pun terlihat semakin terbatas dikarenakan pandemi Covid-19 banyak negara di dunia yang menutup bordernya untuk warga negara asing, sehingga semakin minimnya peluang kerja bagi penduduk usia produktif, maka akan besar pula kemungkinan bonus demografi ini akan terlewati begitu saja tanpa dapat dimanfaatkan dengan baik untuk meningkatkan kesejateraan masyarakat Indonesia. Upaya melakukan pendaya gunakan bonus demografi dan mengaitkannya dengan pendorongan pertumbuhan ekonomi, karena kedua hal tersebut sangatlah penting dan terkait erat karena SDM merupakan komponen paling penting baik sebagai subjek maupun objek dalam proses pembangunan.

\section{B. Pengangguran Dan Penyerapan Tenaga Kerja Indonesia}

Menurut Blomm (2003) dalam Todaro, 2011; ada tiga pendapatan dalam melihat korelasi antara pertambahan penduduk dengan tingkat pertumbuhan ekonomi yakni pendapatan yang menyatakan menolak (restrict), mendukung (promote), dan netral (independen).

Kelompok pemikir yang tergolong dalam mazab neo-Maltusian dipelopori oleh Garret Hardin, kelompok ini menilai bahwa keterbatasan sumber daya alam sebagai sumber ekonomi tidak mampu lagi menampung pertambahan penduduk yang semakin menambah. Secara garis besar, teori pesimis yang dilandasi logika Malthusian maupun Neo-Malthusian menyatakan bahwa pertumbuhan ekonomi akan semakin menurun karena produksi sumber ekonomi yang semakin menyusut. Ketersediaan sumber ekonomi berupa sumber daya alam yang menyusut berpengaruh pada menurunnya pendapatan penduduk secara keseluruhan. Maka dalam konteks ini, membatasi dan mengontrol pertambahan penduduk akan berdampak signifikan terhadap pertumbuhan ekonomi serta perlu upaya untuk membatasi konsumsi ditabung dan menjadi investasi agar tetap dapat mempertahankan pertumbuhan ekonomi.

Berdasarkan data Survei Angkatan Kerja Nasional (Sakernas) dalam Badan Pusat Statistik, dalam kurun waktu tahun 2010 sampai dengan Agustus 2020, jumlah pengangguran di Indonesia mengalami kondisi yang fluktuatif. Tingkat Pengangguran Terbuka (TPT) di Indonesia juga mengalami kenaikan. Pada tahun 2014 tingkat pengangguran terbuka (TPT) di Indonesia pada Februari 2014 hanya turun 0,12\% menjadi $5,70 \%$ dari periode yang sama tahun sebelumnya 5,82\%. Tingkat Pengangguran Terbuka (TPT) mengalami penurunan sejak tahun 2015 sampai dengan tahun 2019. Pada Agustus 2019, TPT turun menjadi 5,28 persen dibandingkan tahun lalu yang sebesar 5,34 persen. Terdapat 5 orang penganggur dari 100 orang angkatan kerja di Indonesia. Tingkat 
pengangguran terbuka (TPT) Agustus 2020 sebesar 7,07 persen, meningkat 1,84 persen poin dibandingkan dengan Agustus 2019.

Tingkat pengangguran terbuka (TPT) Agustus 2020 sebesar 7,07 persen, meningkat 1,84 persen poin dibandingkan dengan Agustus 2019. Terdapat 29,12 juta orang (14,28 persen) penduduk usia kerja yang terdampak Covid-19, terdiri dari pengangguran karena Covid-19 (2,56 juta orang), Bukan Angkatan Kerja (BAK) karena Covid-19 (0,76 juta orang), sementara tidak bekerja karena Covid-19 (1,77 juta orang), dan penduduk bekerja yang mengalami pengurangan jam kerja karena Covid-19 (24,03 juta orang). Jumlah angkatan kerja pada Agustus 2020 sebanyak 138,22 juta orang, naik 2,36 juta orang dibanding Agustus 2019. Sejalan dengan kenaikan jumlah angkatan kerja, Tingkat Partisipasi Angkatan Kerja (TPAK) juga naik sebesar 0,24 persen poin. Penduduk yang bekerja sebanyak 128,45 juta orang, turun sebanyak 0,31 juta orang dari Agustus 2019. Lapangan pekerjaan yang mengalami peningkatan persentase terbesar adalah Sektor Pertanian (2,23 persen poin). Hal ini sejalan dengan maraknya Pemutusan Hubungan Kerja (PHK) akibat sudah tak tahan melawan pandemi. Tercatat banyak perusahaan kecil dan menengah terdampak paling berat akibat pandemi ini sehingga pada akhirnya harus gulung tikar dan memutuskan hubungan kerja kepada karyawan-karyawannya, tidak hanya itu perusahaan perusahaan besar bahkan BUMN pun melakukan banyak perombakan besarbesaran terhadap karyawannya.

World Health Organization mengumumkan pada tanggal 11 Maret 2020 bahwa COVID-19 merupakan sebuah pandemi. Pandemi ini ditetapkan akibat terjadinya lonjakan kasus terkonfirmasi Covid-19 yang cukup tajam pada selama dua minggu di negara-negara tertentu, seperti Amerika Serikat, Spanyol, Italia, Jerman, dan lain sebagainya yang secara langsung juga meningkatkan jumlah terkonfirmasi di negara-negara lain akibat pengecekan masal pada banyak negara, khususnya negara yang berbatasan langsung dengan negara tersebut. Selain itu, Negara dari benua lain berpotensi pula tertular COVID-19 akibat perpindahan masyarakat yang pergi dan kembali setelah melakukan perjalanan ke luar negeri. Kurangnya tingkat kesadaran masyarakat Indonesia pada awal pemutasian virus ini mempengaruhi cepatnya penularan yang membuat kurva penularan di Indonesia terus meningkat. Akibat dari pemutasian virus covid-19 beberapa pemerintah daerah di Indonesia melakukan beberapa kali perpanjangan PSBB atau Pembatasan Sosial Berskala Besar untuk mengurangi tingkat penularan COVID-19, yang menjadikan dampak yang sangat besar pada banyak sektor perekonomian di Indonesia. Dari sektor ekonomi kreatif dan pariwisata di Indonesia adalah sektor tertinggi penyumbang pengangguran selama masa pandemi ini. Menurut data E-Conomy SEA 2020 sektor yang paling dirugikan dari pandemi Covid-19 ini adalah sektor travel dan Transportasi dengan minus lebih dari 13 persen. Selain PSBB pemberhentian kegiatan yang melibatkan masyarakat dalam jumlah banyak dan kampanye "dirumah aja" dan himbauan tidak melakukan perjalanan dalam tujuan berlibur menyebabkan terjadi kematian pada sektor ini dan berdampak signigfikan pada semakin banyak jumlah penganguran di Indonesia. Peluang kerja diluar negara Indonesia pun terlihat semakin terbatas dikarenakan banyak negara di dunia yang menutup bordernya untuk warga negara asing, sehingga semakin minimnya peluang kerja bagi penduduk usia produktif.

Menelaah dari data yang ada, jika dilihat dari proyeksi dan keadaan ekonomi Indonesia dimasa sekarang, bonus demografi Indonesia menjadi sebuah hal yang agaknya jauh dari kata menguntungkan. Keadaan pandemi Covid-19 ini membuat semua negara harus survive terhadap negaranya masing-masing karena kondisi ini terjadi di seluruh dunia dan mengancam banyak sektor. Ini sangat perlu kita kritisi, meskipun pemerintah sudah mengeluarkan beberapa program seperti Kartu PraKerja dan PEN untuk UMKM, kebijakan yang dilakukan pemerintah ternyata ini tidak cukup mampu untuk menahan laju pengangguran kita. 


\section{Kesimpulan}

Bonus demografi yang diterima bangsa kita pada tahun 2020 sampai tahun 2030 merupakan bagian tak terpisahkan dari laju pertumbuhan penduduk di Indonesia saat ini. Melimpahnya penduduk usia kerja di Indonesia merupakan suatu peluang bagi pemerintah baik pemerintah pusat maupun pemerintah daerah. Peningkatan penduduk usia 15 - 64 tahun pada tahun 1970 jumlahnya mencapai lebih dari 64 juta jiwa dan telah berkembang menjadi lebih dari 138 juta jiwa, atau mengalami kenaikan lebih dari dua kali lipat pada saat ini. Rasio tingkat ketergantungan penduduk Indonesia pun sempat mengalami penurunan menjadi 49 pada tahun 2015. Tingkat pengangguran terbuka (TPT) Agustus 2020 sebesar 7,07 persen, meningkat 1,84 persen poin dibandingkan dengan Agustus 2019 dan meningkat pesat jika dibandingkan selama sepuluh tahun terakhir. Terdapat 29,12 juta orang (14,28 persen) penduduk usia kerja yang terdampak Covid-19. Tercatat banyak perusahaan kecil dan menengah terdampak paling berat akibat pandemi ini sehingga pada akhirnya harus gulung tikar dan memutuskan hubungan kerja kepada karyawan-karyawannya, tidak hanya itu perusahaan perusahaan besar bahkan BUMN pun melakukan banyak perombakan besar-besaran terhadap karyawannya.

Sektor travel dan Transportasi dengan minus lebih dari 13 persen karena adanya PSBB, himbauan tidak melakukan perjalanan dalam tujuan berlibur, serta penutupan border bagi wisatawan asing masuk dan keluar wilayah Indonesia. Menelaah dari data yang ada, jika dilihat dari proyeksi dan keadaan ekonomi Indonesia dimasa sekarang, bonus demografi Indonesia menjadi sebuah hal yang agaknya jauh dari kata menguntungkan. Keadaan pandemi Covid-19 ini membuat semua negara harus survive terhadap negaranya masing-masing karena kondisi ini terjadi di seluruh dunia dan mengancam banyak sektor.

\section{Saran}

Berdasarkan hasil uraian diatas perlu adanya tindakan yang sangat serius yang dilakukan oleh pemerintah mengingat laju Bonus Demografi yang baru akan bertumbuh di mulai di era pandemi ini sampai pada puncaknya sepuluh tahun kedepan agar Bonus Demografi dapat menjadikan sebuah moment yang menguntungkan bagi Indonesia. Indonesia mungkin perlu sedikit belajar dari Tiongkok dan Korea Selatan dalam memanfaatkan bonus demografi, dengan cara menciptakan industri-industri rumah tangga memproduksi berbagai komponen dalam wadah ekonomi mikro dan menengah guna menyerap banyak tenaga kerja dan sebagai salah satu langkah meningkatkan perekonomian Indonesia. Pemberdayaan peningkatan kualitas Sumber Daya Manusia juga sangat perlu untuk dikebut, pelatihan-pelatihan dan pembelajaran gratis perlu dilakukan oleh pemerintah demi mengembangkan wawasan masyarakat mengingat sebuah negara harus bergantung penuh pada keberlangsungan negaranya sendiri dari segala sektor.

\section{Daftar Pustaka}

[1] Adioetomo, Sri Moertiningsih, 2005, Bonus Demografi : Hubungan antara Pertumbuhan Penduduk dengan Pertumbuhan Ekonomi. Jakarta:BKKBN

[2] Badan Pusat Statistik,2015, Profil Penduduk Indonesia Hasi SUPAS 2015. Jakarta: Badan Pusat Statistik

[3] Badan Pusat Statistik, 2019, Berita Resmi Statistik 5 November 2019. Jakarta: Badan Pusat Statistik

[4] Badan Pusat Statistik, 2020, Berita Resmi Statistik 5 November 2020. Jakarta: Badan Pusat Statistik 
[5] Jati, Wasisto Raharjo,2013. BonusDemografi Sebagai MesinPertumbuhan Ekonomi:Jendela Peluang Atau Jendela Bencana Di Indonesia

[6] Srihadi, Endang, 2012, Bonus Demografi :Jendela Kesempatan atau Jendela Bencana, Update Indonesia 7(1): 2-8

[7] Todaro, Michel, 2011, "EkonomiPembangunan di Dunia Ketiga" edisi Terjemahan, Erlangga. 